Chapman University

Chapman University Digital Commons

Sociology Faculty Articles and Research

Sociology

2004

\title{
Transnational Labor Mobilizing in Two Mexican Maquiladoras: The Struggle for Democratic Globalization
}

Victoria Carty

Chapman University, carty@chapman.edu

Follow this and additional works at: http://digitalcommons.chapman.edu/sociology_articles

Part of the International and Comparative Labor Relations Commons, International Business Commons, International Economics Commons, Labor and Employment Law Commons, Labor Economics Commons, Unions Commons, and the Work, Economy and Organizations Commons

\section{Recommended Citation}

Carty, Victoria. 2004. "Transnational labor mobilizing in two Mexican Maquiladoras: The struggle for democratic globalization." Mobilization: An International Quarterly 9(3): 295-310.

This Article is brought to you for free and open access by the Sociology at Chapman University Digital Commons. It has been accepted for inclusion in Sociology Faculty Articles and Research by an authorized administrator of Chapman University Digital Commons. For more information, please 


\section{Transnational Labor Mobilizing in Two Mexican Maquiladoras: The Struggle for Democratic Globalization}

\section{Comments}

This article was originally published in Mobilization: An International Quarterly, volume 9, issue 3, in 2004.

\section{Copyright}

San Diego State University 


\title{
TRANSNATIONAL LABOR MOBILIZING IN TWO MEXICAN MAQUILADORAS: THE STRUGGLE FOR DEMOCRATIC GLOBALIZATION
}

\author{
Victoria Carty ${ }^{*}$
}

\begin{abstract}
The struggle to improve workers' rights in Mexican maquiladoras and export processing zones elsewhere in the world is central to the politics of global economic integration. Statecentered development is increasingly compromised by supranational institutions and trade agreements. Meanwhile, multinational corporations are relocating at an unprecedented rate to overseas locations. Export processing zones are notorious for poor working conditions and result in a "race to the bottom." The maquila sector in Mexico is a prime example of this phenomenon. This article uses two case studies to examine ways in which grassroots organizing has successfully resisted low wages and poor working conditions through international network building and information sharing. It combines social movement theory with the literature on international relations to conceptualize the internationalization of grassroots efforts to pressure multinational corporations and host governments to respect labor laws included in international trade agreements, national standards, and self-mandated corporate codes of conduct. Key to the success in both cases has been the role that nonstate actors played in domestic and international politics, operating outside of national borders to simultaneously target the local, national, and international level.
\end{abstract}

There is a vigorous debate underway regarding how the global economy should be governed; who should govern it, and whose interest it should serve (Faux 2002). Campaigns to improve workers' rights in export processing zones (EPZs) are politically at the center of this debate. Scholars and activists interested in understanding and bettering working conditions in developing countries must come to terms with two major trends in the global economy. One is the increasing subordination of state-centered development by powerful supranational institutions and trade agreements, which dictate the rules for countries integrating into the global economy. The state is often unwilling or unable to direct foreign capital in a way that benefits local industries and workers, as global arrangements are altering domestic political structures and constraining state decisions. Another concern is that multinational corporations (MNCs) are closing manufacturing plants in the United States at an unprecedented rate and relocating production sites overseas in EPZs. According to many critics, these zones are notorious for substandard working conditions, low pay and antiunion behavior.

The recent accelerated economic integration, the growing numbers of international institutions and treaties, the increasing power and autonomy of MNCs, and emerging issues that transcend national boarders have increased transnational contentious politics (Rucht 1999). To counteract some of the ill effects of global economic arrangements on local populations, nonstate actors are mobilizing from below to challenge the authoritarianism and

\footnotetext{
* Victoria Carty is Assistant Professor of Sociology at Niagara University, Niagara Falls, NY 14305. Please address correspondence to her at: vcarty@niagara.edu
}

(C) Mobilization: An International Journal 9(3):295-310 
practices of states and international institutions (Falk 1997; O'Brien et al. 2000).

This article uses two case studies of labor struggles in Mexican maquiladoras to examine forms of resistance to corporate global capitalism. It explores some of the strategies and organizing tools participants are employing to enhance international network building and information sharing. It specifically analyzes attempts to increase wages and improve working conditions through unionization at two plants in the maquila industry in Mexico.

Although Tarrow (1998) points out that globalization and transnational activism are not new, there is growing research interest in transnational advocacy networks (TANs) and international political opportunity structures (POS). This analysis utilizes these frameworks to conceptualize the internationalization of grassroots efforts among workers, activists, and other political actors to pressure MNCs and host governments to respect labor laws included in international trade agreements, national standards, and self-mandated corporate codes of conduct. The case studies contribute to our theorization of transnational social movement activity by shedding light on how activists mobilize around local issues in transnational networks. By framing their claims globally, activists have been able to gain support from transnational networks, coalitions, and NGOs in local struggles. This research demonstrates the important role nonstate actors can play in domestic and international politics when they are able to operate outside of national borders to simultaneously target the local, national and international level.

\section{RECENT TRENDS IN THE GLOBAL ECONOMY}

The past few decades have brought about intensified processes of globalization under which neoliberal strategies emphasize market-oriented approaches to economic development (Strange 2000; Mann 2000; Dicken 1998). The term globalization loosely refers to an increase in the scale, scope and velocity of flows of information, technology and trade (Castells 1989). These changes make national economies increasingly susceptible to international pressures, as international organizations have assumed greater power over global economic forces and local political processes (Smith and Johnston 2002). The ability of host governments (as well as labor) to regulate and control trade and foreign investment is constrained by an increasing matrix of commitments to trade agreements and other international actors (Faux 2002; Dicken 1998). Trade agreements such as the North American Free Trade Agreement (NAFTA) tend to be controlled by the wealthy, industrialized nations that set the agenda to protect the interests of foreign investors and the mobility of capital in supply chains, but do little to protect the interests of labor (Basu 2001; Connell 2001).

Another major constraint for states and labor under global economic restructuring is that MNCs now play a dominant role in the new economic order (Sklair 1998, 1995). As the power of MNCs steadily increases, the ability of the state in lesser developed countries to pursue national goals such as local economic and human development are diminished due to insufficient leverage over global corporate actors (Dicken 1998). Because MNCs tend to subcontract manufacturing where labor costs are lowest, low-income countries must compete with one another to attract foreign investment and to attain employment opportunities (Boswell and Chase-Dunn 2000; Dicken 1998). One way that countries attempt to undercut their competitors is to create EPZs. Foreign investors are attracted to the zones for tax incentives, lax environmental standards, and a guaranteed cheap and compliant workforce (Korten 2001; Rodrick 2000). In some EPZs minimum wages are suspended, unions are forbidden, and benefits, job security and working conditions are very poor (Sklair 1995; Bailey et. al. 1993). Many critics refer to this process as the "race to the bottom" (see Collingsworth 1998; Spar and Yoffe 1999).

Though there is an ongoing debate as to what extent states or global markets are in control of socioeconomic life, there is a general consensus that globalization offers great opportunities for human advance, but only with strong governance (for a detailed discussion 
see Dicken 1998). In EPZs, however, MNCs enjoy an advantage in the balance of power due to particular arrangements under which the interests of workers and governments are compromised in comparison to other sectors of the economy.

Different proposals have been suggested as to how to balance the interests of MNCs with those of labor. Some propose that self-regulation by foreign investors themselves is the best solution because business executives have the leverage to convince host governments to address human rights issues. Others argue that global mechanisms, such as international accords on labor standards, are needed to guarantee basic labor rights. Still other strategies proposed advocate regulation at the national and local level whereby host governments would force foreign investors to obey national laws.

To date, neither the goals nor the enforcement of any of these proposals have been systematically accomplished. What small victories that have been won were achieved through the internationalization of grassroots mobilization that persuaded international, national and/or corporate actors to recognize and enforce legislation protecting workers' rights.

\section{MOBILIZATION FROM ABOVE}

In the 1990s allegations involving the use of sweatshop labor by major brand-name retailers received a lot of attention in the mainstream media and in academic circles. By the late 1990s there was evidence that consumers were willing to express their dissatisfaction with corporate labor abuses through their retail purchasing decisions. According to a 1999 study conducted by Marymount University's Center for Ethical Concerns, $75 \%$ of respondents said that they would avoid shopping at a retailer who is known to sell garments made in sweatshops. Eighty-six percent stated that they would pay an extra dollar on a $\$ 20.00$ garment if they were sure that it was not made in a sweatshop (Fung, O'Rourke, and Sabel 2001). Increased popular pressure against sweatshop labor in part gave rise to two adaptations in labor practices that fall under the rubric of mobilization from above.

\section{Self-Regulation: Codes of Conduct}

Several MNCs took the initiative to legislate working conditions by establishing codes of conduct that they demand their subcontractors adhere to. Despite the initial popularity of these measures among retailers, by the mid 1990s there was widespread agreement that the individual company-mandated codes were seriously flawed (Greenhouse 1997). Workers tended to have little if any knowledge of the codes and subcontractors rarely enforced them. Even when subcontractors did attempt to adhere to them there was no mechanism to do so. To establish more comprehensive reform leaders of the apparel and footwear industries and representatives from human rights and labor rights organizations came up with standard regulations that subcontractors must recognize and enforce. In 1997 they released the Apparel Industry Partnership (AIP) Code of Conduct, which included guidelines on worker rights along with general health and safety regulations (Greenhouse 1997). A subsequent agreement established the Fair Labor Association (FLA) to enforce and monitor the AIP code.

Task force members representing labor and human rights groups soon began challenging the FLA's endorsement of a minimum rather than a living wage. It also condemned its monitoring strategy for being one of corporate governance; under with apparel manufacturers select their own accounting firms to conduct internal and secretive inspections (Featherstone 2002). Overall, opponents of the FLA charged that compliance with the weak standards as implemented by the FLA was merely a public relations tactic designed to defray public interest in sweatshops rather than construct systemic change.

In the late 1990s student participation in the movement began to grow. United Students Against Sweatshops (USAS) formed in 1998 to ensure that their college and university names 
and logos would not be associated with sweatshop labor (Featherstone 2002). Students organized across the country to pressure administration to uphold the manufacturers of collegiate footwear and apparel to a code of conduct. In 1999 when labor, human rights groups and NGOs dropped out of the FLA, these groups together with USAS established the Workers Rights Consortium (WRC). The WRC attempts to help the indigenous worker-allied groups develop their capacities to participate effectively in the monitoring system (Featherstone 2002). The WRC adopts a process of spot checks in response to worker complaints to ensure compliance of national law and codes of conduct. Monitoring is carried out by WRC members in conjunction with local NGO and labor organizations.

\section{Institutional Solutions Through Trade Agreements}

Another mobilization-from-above option is for the international community to standardize worker rights in foreign-owned factories, and that trade agreements contain and provide the same enforcement mechanisms as for other commercial provisions (Connell 2001). As an alternative, some see it as the exclusive role of the ILO to constitutionally set and deal with labor standards.

Currently, neither of these has been vigorously pursued, and the interests of business continue to enjoy advantages over those of workers, the environment, and human rights. Advocates for the inclusion of human-rights guarantees in trade agreements note that supranational institutions and trade agreements such as the WTO entail specific terms of trade and operate according to ground rules that favor corporate and financial interests and that protect trade, investment and intellectual property rights (Winston 2002). However, corporations are not subject to any binding regulations or formal sanctions for failure to respect the human and labor rights (Faux 2002; Winston 2002). The limited clauses that do address labor issues are weak and/or not enforced.

Monitoring is also problematic. For example, the WTO contracts with Social Accountability International (SAI), an organization that administers a code to monitor contractors. It has a commission that can recommend trade sanctions if conditions do not meet the prescribed standards that it holds subcontractors to. However, its standards can bypass ILO standards of freedom of association. For example, in 1998 the SAI clause was used to implement guaranteed normal trade status with China despite its ban on independent unions and collective bargaining by mandating that factory managers can appoint government worker representatives to act on behalf of workers' interests (Gilley 2001). Governments, of course, can also be highly selective in their ratification of ILO labor standards. Reliance on ILO conventions in general has substantial drawbacks because the ILO operates on the basis of consensus among labor, management, and governments; and therefore its actions are necessarily limited to what can be agreed upon by all three actors (Winston 2002).

Another example of how business interests trump labor rights under corporate globalization is the side agreement in NAFTA. It allows workers and interested third parties in the U.S., Mexico and Canada to file complaints when a government is failing to enforce its own labor legislation (Fung, O'Rourke, and Sabel 2001). However, it does not allow for similar motions against corporations for labor rights violations, or address the problem of weak and deteriorating labor standards in national legislation. Though there have been dozens of complaints filed against both Mexico and the U.S.charging an unwillingness to enforce workers' rights, not a single independent union has been able to negotiate a contract as a result of any NAFTA ruling (Bacon 2001). Also, MNCs can easily evade international or national standards by moving their production facilities elsewhere (Winston 2002).

A final problem is that there is much resistance to universal labor standards in developing countries themselves. Many governments fear that such standards and monitoring efforts will serve as an instrument of protectionism for the North to impose arbitrary and inflexible trade sanctions on Third World countries (Basuu 2001). 


\section{MOBILIZATION FROM BELOW}

The concerted grassroots efforts of workers and activists in host countries, in conjunction with those at the transnational level, have in a few cases successfully pressured governments, brand producers, and their subcontractors to adhere to labor laws and codes of conduct. The following case studies illustrate the importance of targeting local, national, and international levels to improve working conditions in EPZs, and how these different spheres can be mutually reinforcing. A decisive factor in each case has been whether or not the host government can be forced to take a proactive role in helping to resolve conflicts between foreign capital and labor.

\section{Labor Mobilization at the Kukdong Plant}

In January of 20019,800 workers went on strike at the Korean-owned Kukdong factory in Puebla, Mexico. The strike was in reaction to a host of substandard conditions including the use of child labor, failure to pay the minimum wage and the firing of union leaders (Kepne 2000; Verite 2001). Also, workers were also forced to sign with the government-mandated CROC (Revolutionary Confederation of Workers and Peasants) union in order to be employed. After a three-day strike a police crackdown ensued and state police attacked the workers guarding the factory. Fifteen workers were hospitalized, and five organizers of the strike were fired (Bacon 2001). Nike Corporation was one of the largest manufacturers doing business with Kukdong, producing sweatshirts for many big-name universities.

A diverse network of support for the workers mobilized among student, labor, and other human rights groups across the North and South. The workers used the power of the growing anti-sweatshop movement in the United States to reinforce their efforts. They contacted the Mexico City office of the AFL-CIO, which helped Kukdong workers publicize their case on US and Canadian campuses (Bacon 2001). Across the country, at universities that had contracts with Nike students pressured administrators to threaten Nike with termination of these contracts if they did not help to rectify the situation. They used creative forms of resistance to raise awareness about the issue. They organized speaking tours for Kukdong workers across the country, held sit-ins and occupied administrative offices, leafleted on campus and outside of NikeTowns, staged rallies, and held mock fashion shows sporting Nike gear with information about where and under what conditions the footwear and apparel was being made (Featherstone 2002). Representatives of USAS and the WRC, in conjunction with WRC's monitoring agency Verite and the International Labor Rights Fund (ILRF), also went to the Kukdong factory and verified the workers complaints (CLR 2002)

Support was also provided by the Workers Support Centre (CAT) in Mexico, students at the Autonomous University of Puebla, the AFL-CIO, and Campaign for Labor Rights (CLR), the United States Labor Education in the Americans Project (US/LEAP), Sweatshop Watch, the European Clean Clothes Campaign, Global Exchange, the Maquila Solidarity Network (MSN) and the Korean House for International Solidarity.

Thus, the mobilization to sustain the workers' campaign was a multi-level, multi-task strategy targeting the local, national and international level. At the local level, the workers staged a walkout to disrupt the accumulation of capital at the level of production. At the national level, in solidarity with the workers, activists pressured the Labor Secretary in Mexico and the Mexican Cabinet Secretary. And globally, they pressured the Global Director for Labor Practices at Nike, Kukdong International (Mexico), and Kukdong Corporation Korea (Korea) to resolve the dispute. Their demands also cut across the local national and international dimensions. They insisted that management comply with Mexican labor laws, Nike's code of conduct, the respective universities' codes of conduct, and the international agreement regarding the right of freedom to organize.

NGOs played an instrumental role in the organization and information sharing aspect of the campaign, most of which was done via the Internet. MSN, Global Exchange, and CLR in 
particular were fundamental in organizing the broad network of activists. CLR's' action alerts that circulate on the web requested that concerned citizens send letters to Nike demanding the corporation support a fair negotiation process between the workers and the factory management. CJM and Global Exchange also had frequent updates on their websites and published these on various labor-oriented list serves and email listings.

After receiving letters from over 6,000 people from seventeen countries, in a unique move Nike declared it would not abandon production orders at Kukdong but preferred the situation be rectified between management and workers, and that management meet their legal responsibilities (Maquila Solidarity Network 2001). Nike released its plan outlining the corrective actions and a timetable for Kukdong to comply with Nike's code of conduct. Through letters and contact with Mexican government officials, Nike urged respect for freedom of association and requested an expedited review of any forthcoming application for an election of a new union (WRC 2002).

However, the conflict was not solved easily or quickly. Weeks of intimidation ensued at the factory and managers refused to allow organizers of the strike to return to work. Eventually, management did succumb to pressure from local and international protestors and pressure from Nike. The organizers of the strike were eventually allowed to return to work and charges were finally dropped against two of the five leaders as demanded by Nike. After a nine month strike, workers successfully established their own union and negotiated a contract with the Korean owners. At Kukdong, now renamed Mexmode, an independent union replaced the CROC union and workers received a wage increase of $10 \%$, a $5 \%$ increase in cash benefits, and attendance bonuses (Kidd, 2001). Workers now make up to $40 \%$ more pay than they were making under the old contract. In addition, the Mexico City office of the ILO conducted freedom of association training and provided technical assistance to the factory at Nike's urging (Kidd 2001).

International solidarity at the grassroots level unequivocally played a significant role in the success of this campaign. Speaking at the University of Michigan, Marcela Mnoz Tepepa, a seamstress at the Kukdong factory who helped to initiate the work stoppage stated, "Without the dialogue at the University of Michigan it would have been impossible to win the struggle. This is one of the reasons we continued to struggle . . because we knew we had your support" (Schrader 2002).

Maria Eitel, vice-president and senior advisor on corporate responsibility for Nike Corporation, also credits the protesters' actions for bringing these issues to Nike's attention and the ultimate concessions. She states, "I don't think Nike would have made the kind of progress it has made if we hadn't been attacked" (Cave 2002). Additionally, Dusty Kidd, the

\begin{abstract}
We believe collaboration can yield positive, successful results for workers in delicate situations like Kukdong/Mexmode. Companies like Nike . . can make an immediate impact in reaching resolution because we have the ability to place or terminate orders which can affect the factory's ability to be profitable and attract other buyers." (quoted at http://www.nikebiz.com)
\end{abstract}

Thus, the case of Kukdong supports the idea that corporations can have a positive impact on forcing host governments to abide by certain standards regarding labor and human rights. However, it was only through the intense and constant pressure put on Nike which led the corporation to urge government officials and its subcontractors to take action, and which led to change at least at the factory level.

The overall success for the workers was due to organizing, solidarity, and corporate campaign strategies in enforcing concessions among retailers, their subcontractors and local governments to respect workers' rights. The combined efforts of students, university administrations, NGOs, unions and labor rights organizations created sufficient democratic space for the workers to organize and win their independent union. While pressure on Nike was crucial in helping workers achieve their victory, and lobbying of the Mexican government 
helped win the registration of the independent union, ultimately it was this transnational grassroots networking that empowered the workers and enabled them to have a voice in the decision-making process. The Kukdong struggle is therefore an excellent example of how globalization from below can be an effective strategy in at least slowing the race to the bottom.

On the other hand, this case also illustrates the limitations of the social clause in the NAFTA agreement that does not allow workers to challenge MNCs directly. Organizers had to operate outside of the legislative realm of any established trade agreement. It also highlights some of the flaws in the corporate-driven self-monitoring process. Although Nike's social responsibility department currently employs 100 people, and it has tripled its budget since 1998 and spent $\$ 500,000$ on global reporting initiatives (including those produced by the FLA), it was only through independent verification monitoring mechanisms that workers' rights came to be respected (Cave 2002).

\section{Mobilization at the Duro Plant, Río Bravo, Mexico}

In June of 2000 workers at the Duro plant in Río Bravo went on strike to establish an independent union and force the reinstatement of their elected leaders who were illegally fired (CLR 2000). Duro produces gift bags for retailers such as Hallmark, Neiman Marcus and the GAP. In August 2000, Mexican government officials granted official registration to the Duro workers independent union. This was the first independent union to win registration in decades in the state of Tamaulipas and forced a representation election. Like the union at Kukdong, this independent union competed with the government-controlled CROC union. With the help of the FAT (Authentic Workers Front) the workers presented over 400 signatures on a petition for the election to the Conciliation and Arbitration Board (CAB) in Mexico City on September 28, 2000 (Bacon 2001).

Elections to vote on union membership were held in March 2001, but were conducted in the midst of threats of violence and reprisals by the company and CROC "enforcers" (Bacon 2001). Out of 1400 workers, only 502 voted and the four workers who voted for the independent union were fired (Bacon 2001). Workers had been escorted to the voting area by CROC organizers and were forced to verbally declare their choices. While campaigning for president, Vincente Fox promised reforms to establish secret-ballot union elections (MHSSN 2001). Not only was this right neglected, but during the ensuing firings, intimidation, and physical abuse the government did nothing to protect the workers' rights.

In October of 2001 the union was taken over by members of the CROC union, which conducted a secret election of the independent union's Executive Board without the knowledge or participation of the union's members (CLR 2001). The CROC move, backed by local government authorities, was designed to prevent the independent union from contesting the March election as a violation of the workers' right to a secret ballot election (MHSSN 2001). This was in direct violation of the Joint Declaration signed by the labor ministers of Mexico and the United States (as part of the NAFTA agreement), in which Mexico pledged to promote "the use of eligible voter lists and secret ballot elections in disputes over the right to hold the collective bargaining contract."

Again, NGOs and their links with other grassroots organizations coordinated efforts to play an essential role in the struggle. CLR organized letter-writing petitions to Hallmark to uphold its code of conduct, which ensures freedom of association (Bacon 2001). It also sent out action alerts asking people to email, call, fax, and write the CEO of Duro Bag Manufacturing Company and tell him to reinstate the workers, pay all workers their due amount of severance pay according to the Mexican Federal Labor Law, and improve conditions at the Duro factory (CLR 2001).

Duro workers were also supported from the North by the Coalition for Justice in the Maquiladoras (CJM). This NGO has over 100 member organizations, including North 
American unions, churches, and community organizations; and serves as a bridge between workers, researchers, and activists in all three NAFTA countries. The CJM coalition demonstrated with signs and banners demanding that the right to freedom of association be upheld wherever Tomas Yarrington, the governor of Tamaulipas, made a public appearance. They also confronted police outside the plant where the workers were striking, and camped out in Río Bravo's main plaza when police physically removed them from the factory. When CJM activists were arrested for refusal to leave, the coalition sent hundreds of letters, emails, and faxes to media outlets and NGOs regarding the abusive behavior of Duro company officials (Bacon 2001).

In addition, CJM arranged for the Mexican Association of Democratic Lawyers to provide legal counsel and for the Transnational Information Exchange to sponsor a speaking tour in the U.S. and Canada for a former Duro worker. It then incorporated the assistance of the Interfaith Committee for Corporate Responsibility and the Marin Interfaith Task force to arrange a meeting with executives of Duro clients to press the company to abide by the Mexican Labor Board's resolution and to reinstate the Duro workers with back pay or severance pay. CJM members also sent letters to all Duro Company clients to pressure the Duro Company into abiding by the $\mathrm{CAB}$ resolution that secured legal recognition of the independent union (CLR 2003).

In March 2003, the company finally agreed to meet the workers' demands during a conference call between the Duro Company, CJM, and Hallmark, one of Duro's most important clients. The legal battle lasted almost three years, but Duro workers were able to establish an independent union, and those that were illegally fired received full severance pay and back wages (CLR 2003).

The situation at Duro again shows the effectiveness of mobilizing from below, and the inability of treaties like NAFTA to provide sufficient mechanisms to protect workers' rights. Although the labor ministers of the United States and Mexico signed an agreement ensuring secret ballot elections, this agreement was not respected. It also demonstrates the lack of state support for national labor laws and the tendency among national and state governments to appease MNCs in an effort to promote investment under neoliberal reforms at the expense of the legal rights of workers to unionize (Bacon 2001). As was the case at Kukdong, it was only through consistent organization at the micro level across the North and South that activists gained sufficient leverage to press retailers and government officials to respond to the workers' demands and to obtain policy change. The disruptions at the local level and at the site of production, combined with networking at the national and international levels gave the workers the leverage they needed to have their demands met.

\section{GLOBALIZATION AND PROTEST STRATEGY AT KUKONG AND DURO}

McAdam, McCarthy, and Zald define mobilizing strategies as "those collective vehicles, informal as well as formal, through which people mobilize and engage in collective action" (1996: 3). The success or failure of these strategies is influenced by the available political opportunity structures (POS) at the specific historical juncture, which either constrain or provide incentives for collective action (Tarrow 2001, 1998). These POS operate at both the domestic and international level.

Recent social movement research has begun to recognize the implications of globalizing trends and how they affect collective action (Smith et al. 1997; Keck and Sikkink 1998; della Porta et al. 1999). Smith and Johnston (2002) argue that since globalization brings with it substantial changes in the types of contemporary social relations, the ways that people engage in collective political action is transformed as well. These changes have been accompanied by emerging political institutions that create both opportunities and constraints for activists. As globalization continues to reduce the state's ability to act on its own behalf, transnational social movement organizers are now directing more of their resources toward international 
linkages and partnerships (Guidry, Kennedy, and Zald 2000).

Therefore, much of the current research on social movements is incorporating the literature on international relations - particularly the branch that explores the dynamic intersection of domestic politics and the international system. Social scientists have begun to analyze more vigorously how international pressures influence domestic POS, how social movements operate in both a domestic and international environment, and the importance of international networks in local mobilization (Rothman and Oliver 2002; Tarrow 1999; McAdam 1996). Scholars of contentious politics that work within the tradition of international relations have made some important advances in improving social movement theories about global integration and its effects on political contention both nationally and transnationally (Smith and Johnston 2002).

The maquiladoras in Mexico are an excellent example of how globally mandated neoliberal strategies are fast shaping domestic politics. They have also created new institutional mobilizing structures and opportunities for transnational allies to mobilize across borders against common targets (Ayres 2002). The explosion of transnational social movement activity highlights the challenges to the neoliberal doctrine and the beginnings of a new global political space (Falk 1993; Guidry, Kennedy, and Zald 2000). The activists in the struggles in the Mexican maquila industry, for example, were able to identify links between new social structures and new forms of collective action. The response by CJM, CLR, MSN and Global Exchange are good representations of how new institutional opportunities are being created in response to the global race to the bottom. These NGOs provided an overarching forum for the exchange of information and communication among activists that helped expedite the campaigns and enhance coalition building.

The success of the Kukdong and Duro campaigns shows that the state does not have to be directly or solely targeted, but it can be forced to respond to civil society's demands through other mechanisms. Michael Mann (2000: 13) describes how new solutions to social problems are developing in what he calls "interstitial locations." These consist of the "nooks and crannies in and around the dominant institutions." He argues that groups that are marginal and blocked by the prevailing institutions can link together and cooperate in ways that transcend these institutions. Such movements create "subversive invisible connections across state boundaries and the established channels between them. . . . These interstitial networks translate human goals into organizational means" (2000: 13). The actors engaged in the mobilizing strategies in the maquiladoras were forced to make use of such interstitial locations because they were locked out of the international and national dialogue regarding trade regulations.

Global forces have altered the domestic political climate in Mexico in a number of ways. As a result, there is much resentment toward international trade agreements such as NAFTA among much of the local population. For although a significant number of jobs crossed the border since the inception of NAFTA, real wages in Mexico have steadily decreased in the maquila industry. Part of this is due to an abundant labor supply. One of the concessions the government made when signing the NAFTA agreement was to rescind Article 27 of the Mexican Constitution that guaranteed the use of communal lands to the indigenous population. This land is now being sold to foreign corporations and is forcing many subsistent farmers to look for employment in the manufacturing industry. Also as a result of NAFTA, the United States is free to export cheap, subsidized corn on the Mexican market. The result is that farmers can no longer afford to grow corn in Mexico. As the bottom drops out of the agricultural sector, farmers are forced from their land and again end up migrating to the overcrowded cities along the border. In response, the groups affected are using contentious politics by working outside the legitimate political structure to create their political opportunities. The Zapatista uprising is indicative of this. The rebellion in 1994 was in direct response to the signing of NAFTA, as the Mayan Indians in Chiapas foresaw the damaging 
impact the neoliberal agenda would have on their local communities. With institutional channels of claims making closed, armed insurgency was their response.

In the manufacturing sector, a similar uprising is happening. There is a growing realization that the wealthy elites in the North and South set the agenda for all others through these types of trade agreements - typically at the expense of labor, environmental and human rights concerns. Therefore, while NAFTA strengthens the ability of those in power to impose their will on more marginalized groups, it has also enhanced the connection between workers in the North and South as they came to recognize that they share a common enemy in their respective struggles. Jobs have been exported from the North to the South on an unprecedented scale. This means jobs for workers in Mexico, but under exploitative conditions. This has negative consequences for workers in both countries. To combat these forms of abuse workers are collectively focusing their anger on what they understand to be the collusion between the elite representatives of MNCs and governments that work on behalf of business interests rather than on those of their citizens. Thus, the treaty served to create and/or recharge a number of international support groups and coalitions, such as CJM, CLR, LRC and Global Exchange that have carved out a political space to make claims against MNCs and government abuse (Bandy and Mendez 2003).

This convergence is occurring because globalization is creating common interests (respect for environmental, worker and human rights) that transcend both national and interest-group boundaries. By facilitating flows of information across national borders, organizations with transnational ties helped cultivate movement identities, transcend nationally defined interests and build solidarity with a global emphasis (Smith 2002).

According to McAdam, McCarthy, and Zald (1996), another factor that increases the likelihood of protest is a decrease in the capacity or propensity of repressive states to intimidate workers and activists. Mexico had one of the oldest one-party governments in the world, which took the form of a semiauthoritarian state. Like many developing countries, it historically combined repressive production sites with political exclusion in order to secure a safe environment for foreign investment (Bandy and Mendez 2003). The governmentcontrolled CROC acts as a typical corporatist union - a method of social control to constrain workers while protecting the interests of MNCs. At the factories in Kukdong and Duro, the domination of the CROC union made independent unionization virtually impossible. The expansion of the neoliberal global agenda and the signing of NAFTA further increased pressure on the Mexican government to maintain a controlled workforce.

However, over the past few years Mexico has in some other ways become more democratic. In 2000 the 71 year rule of the Institutional Revolutionary Party (PRI) lost the Mexican presidential elections. This trend toward democratization enhanced the ability of workers to organize, which is a quintessential component of any democratic society. In comparison to other Latin American countries, POS are now more open in Mexico because as Manye (2002) points out, Mexico began its export-led industrialization much earlier. This allowed an independent workers' movement to develop over a longer period of time. Also, the border's location offers opportunities to local resistance in that there is an increased likelihood of international support (Bandy and Mendez 2003).

These case studies illustrate how a combination of open and closed POS can sometimes be simultaneously at play, which can work to the advantage of workers and activists. When domestic groups have open domestic POS and governments that are responsive to its citizens, they do not seek out international institutional access regardless of the source of their problem (Tarrow 1995). They will try to influence their own governments to represent their interests in the international arena. But, when there is a high level of repression, authoritarianism, or both, social movement actors bypass their own target states and look to the transnational arena for international support. The outcome is similar if activists view the government to be unconcerned with their demands, or are working in collusion with international actors at the expense of its own citizens. Seidman states, "Activists who view their national states as 
relatively powerless in the international arena or unresponsive to a particular issue may stress global identities, hoping to attract international support for issues that in a different context have been considered a purely local affair" (2000: 347). This was clearly the case with the labor struggles at Kukdong and Duro. Workers felt that President Fox was more interested in appeasing the MNCs and adhering to stipulations in trade agreements than upholding national laws and responding to legitimate worker grievances. They therefore sought out international support on a number of different levels.

The combination of closed domestic POS and an open international POS initiates what is referred to as the "boomerang effect" (Keck and Sikkink 1998; Risse and Sikkink 1999). To understand the dynamics of external-internal movement linkages, Rothman and Oliver (2002) argue that we must recognize the nature of "nested POS." The dynamics of contention concerning workers' rights in the Mexican maquiladoras can refine our understanding of these processes because they demonstrate the local embeddedness of transnational resistance.

The main source of contention initially was at the factory level, and the main targets of the workers' hostility were the managers and subcontractors at these two plants. However, when workers were denied their legal rights and shut out of any legitimate negotiating process, they began to channel their grievances toward the national and international level. The target then became their government for its failure to enforce nationally established labor laws, MNCs for their unwillingness or inability to uphold their own codes of conduct, and international trade agreements and global institutions that do not provide safeguards for worker rights. Though the source and demands of the campaign began at the local level, in both instances they soon became transnational. The immediate outcome was that workers won the right to bargain collectively at each plant and secured financial rewards in their efforts. However, locally embedded struggles such as these necessitate a global perspective and transnational mobilizing.

As the workers realized how global forces were imposing on their everyday lives, they began to interpret their local experiences in terms of international forces. In response, they sought resolution to their domestic problems beyond the nation-state. When social movement actors are able to make this connection they can transcend local and national identities and interests to oppose state and corporate elites (Smith 2002). In the cases of Kukdong and Duro, activists formed networks to advocate for a stronger governmental role. They simultaneously demonstrated an increased organization in civil society at the local, national, and international level. International and national standards such as freedom of association and minimum wage laws were respected only when non-state local actors linked transnationally with other civil actors to assure their enforcement.

In these types of labor struggles the ultimate goal is to change international policy by shaping individual state decisions. Participants are urged to target their own states in order to push the overall movement's agenda forward (Smith 2002; Guidry, Kennedy, and Zald 2002). Activists appeal to the transnational community with the hopes that they can act back on their states and force them to induct policies and institutional change. The case studies examined here did not lead to this outcome, but an increase in these types of victories may eventually lead to institutional change at the national or international level.

Keck and Sikkink (1998) perhaps most accurately describe the type of mobilizing strategies used in the Kukdong and Duro struggles. They use the term "advocacy networks" to describe similar emerging types of organizations that are voluntary, and through which there are "reciprocal and horizontal patterns of communication and exchange," "operating beyond national boundaries and motivated primarily by shared principled ideas or values. These are based on informal types of action and the actors involved may include NGOs as well as local social movements, the media, churches, trade unions, consumer organizations, intellectuals, parts of regional and international governmental organizations, and parts of the executive and/or parliamentary branches of governments" $(1998: 8,30)$. 
They take on an international dimension when they consist of groups of at least two different nations share information, organizational resources, strategies, and at times political interests and values (Tarrow 2001; Fox 2000). Such networks direct their opposition at power holders in at least one state other their own, or against an international institution or a multinational economic actor. These networks are very flexible and the main bond between the various individuals and coalitions is that they maintain similar values and visions. This flexibility among social movement actors allows them to reach wide and heterogeneous audiences that can organize from different angles to form broad coalitions across various movement domains (Rucht 1999).

One of the primary goals of TANs is to create, strengthen, implement, and monitor international norms (Khagram et. al. 2002). These international norms are sometimes part of the resources and POS actors use to draw others to the cause and to develop their collective beliefs. Preexisting international norms can act as pull factors to facilitate the emergence and growth of the TANs, as NGOs act as facilitators by appealing to international norms to legitimate local grievances. The fact that the AFL-CIO mandated right to organize was not being respected (in addition to national and local labor laws) perhaps drew sympathy from other coalitions concerned with other aspects of social justice to support the workers' struggle.

As an alternative, transnational networks, coalitions and movements may attempt to transform their collective beliefs into international norms (Khagram et al. 2002). The exchanges among activists can often shape new identities and activist frames (Smith and Johnston 2002). Frames are ways of packaging and presenting ideas and are used as a source of persuasive communication to convince others to join a particular struggle (McAdam 1996). When social movement actors build on already existing norms to expand the domain to which these norms apply, it is called "frame bridging" (Snow and Benford 1988). This can also draw others to a cause in that the appeal for justice is put forth in a much more generalized sense. For example, for those involved in the anti-sweatshop campaign and resisting the race to the bottom, framing workers' rights (or the ability to unionize) as human rights issues can attract groups or individuals that share a similar vision but work on different social justice campaigns.

Also, NGOs and other transnational advocates use information, persuasion, and moral pressure to change international institutions and governments (Khagram et al. 2002: 11). They do this by displaying or publicizing norm-breaking behavior to embarrass neglectful political officials or corporations to get them to conform to norms - using what is referred to as the "mobilization of shame." This was an effective tactic in getting retailers, university administers, government officials, lawyers, and the consuming public to acknowledge and to respond to the workers' grievances. It may have also persuaded NGOs and other coalitions that do not deal specifically with labor issues to join the cause.

In the Kukdong and Duro struggles, social movement actors combined conventional and novel forms of repertoires and protest. They petitioned governmental officials, wrote letters to retailers and other significant parties, boycotted certain brand-name retailers, and held strikes, walkouts and sit-ins. The multi-level, synergistic, cross-border organizing demonstrated some innovative strategies as well. Those involved in the mobilization targeted multilateral institutions and individuals. The variety of tactics that they engaged in displayed an awareness of the local/global connection. This was enhanced by "global witnessing" regarding the effects of global economic policies. As Smith's (2002) research also suggests, the AFL-CIO sponsored speaking tours informed the public about economic globalization, the race to the bottom, and its effects on local policies and democratic institutions. The use of this pedagogical style allowed workers in the North to recognize that workers in the South were also victims of NAFTA, and to humanize the conflict. It also created awareness that the struggle is clearly global in scope, and that therefore solidarity across borders would be pertinent in forging a resistance in the form of a "globalization from below." 
Another more novel repertoire, as well as an aspect of globalization that has enhanced the international POS, was the use of innovative technology - the Internet. Smith (2002) argues that electronic activism has in fact been essential for the high level of success among NGOs carrying out their activities. Internet sites, electronic list serves and alternative electronic media networks rapidly disseminate up-to-date information about resistance, which helps to empower a more democratic (online) community (Ribeiro 1998). One of the most hotly debated political topics on the Internet discussed among cyberactivsts is the debate between capitalist interests versus community needs (Ribeiro 1998). The websites and action alerts maintained by the NLC, CLR, CJM and Global Exchange were essential in providing links to educate citizens about international trade agreements, facilitating the dissemination of information, and organizing resistance. Also, for many participants in the Kukdong and Duro labor struggles, the fastest, easiest and perhaps only way to express their concerns to retailers, government officials, subcontractors, or university administrators was through online petitions and email contacts.

This phenomenon, by which amorphous groups of NGOs link online and can descend on a target, has been labeled an "NGO swarm" by David Ronfeldt and John Arguilla in a recent RAND study. They argue that the swarm is incredibly effective because "it has no central leadership or command structure, it is multiheaded, impossible to decapitate. And it can sting a victim to death" (cited in Brecher et al. 2002). This has been an important tool in the globalization from below movement in that these networks lack the funds that their opponents have readily at their disposal. Also, with so much information circulating and organizing happening instantaneously online, it is very difficult for MNCs to effectively do what they do best when faced with public criticism—damage control.

\section{CONCLUSION}

Justice for maquiladora workers is still a long way off as the political apparatus in developing countries continues to protect foreign investors at the expense of labor rights. The case studies provided in this research offer insights into the effects of global forces on the anti-sweatshop campaign. They further illustrate how global processes affect social movement repertories that are forged primarily through local or nationally oriented contention.

Actors in civil society are increasing their capacity to influence policy to try to strike a more fair balance between global capital and workers' rights. Though there is no antisystemic movement rapidly emerging upon the scene, numerous interconnected movements and networks are negotiating spaces to democratize the global economy. As this research shows, NGOs in conjunction with other groups are becoming increasingly threatening to foreign investors and the political apparatus that protects them.

The successes at Kukdong and Duro were due to the coordination and reinforcement of different synergistic strategies between different agents and coalitions. These cut across national boundaries to link activist groups in developed countries with labor and community groups in the global South. Cross-national networks of solidarity that linked grass roots organizers in the factories with students, labor and human rights groups achieved the greatest success in pressuring brand-name retailers, local manufacturers, and local authorities to improve wage levels and working conditions. Grassroots efforts were far more effective than alternative "top-down" mechanisms such as corporate codes of conduct or supranational initiatives such as NAFTA or the WTO. However, they succeeded only when the state was forced to play a proactive role in protecting worker rights. Thus, the ultimate goal must be to ensure workers have a democratic space to pressure their governments to enforce their rights. Both a stronger governmental role and increased organization in civil society are needed to ensure that workers' rights are upheld.

In the future, the empowerment of local and national communities and politics will 
require a degree of global regulation and governance because they are interdependent. For example, unless the ILO standards of freedom of association are respected by national governments, MNCs, and international trade agreements, workers will have no power to even attempt to make demands. Once their grievances are aired democratically, and perhaps resolved, this resolution may some day be institutionalized and respected more broadly at the national and international level. Thus, making the local/global connection is essential for social movement actors involved in the labor struggles in EPZs. For it was only by establishing greater control over global capital that the workers were able to establish greater control over their own economic lives. If we want to establish a democratized type of globalization from below in a true sense, institutions at the local, national and global level must be made accountable to those that they affect.

\section{REFERENCES}

Ayres, Jeffery M. 2002. "Transnational Political Processes and Contention Against the Global Economy." Pp. 191-205 in Globalization and Resistance: Transnational Dimensions of Social Movements, Hank Johnston and Jackie Smith, eds. Lanham, MD: Rowman and Littlefield Publishers.

Bacon, David. 2001. "NAFTA's Side Agreements Fails." In These Times. April 16.

Bailey, Paul, Aurelio Parisotto, and Geoffrey Renshaw. 1993.Multinationals and Employment: The Global Economy of the 1990s. Geneva: International Labour Office.

Bandy, Joe, and Jennifer Mendez. 2003. "A Place of Their Own? Women Organizers in the Maquilas of Nicaragua and Mexico.” Mobilization: An International Journal 8(2): 173-188.

Basu, Kaushik. 2001. "The View From the Tropics." Pp. 59-64 in Can We Put An End to Sweatshops? Archon Fung, Dara O'Rourke, and Charles Sabel, eds. Boston: Beacon Press.

Boswell, Terry and Christopher Chase-Dunn. 2000. The Spiral of Capitalism and Socialism: Toward Global Democracy. Boulder: Lynne Rienner Publishers.

Brecher, Jeremy, Tim Costello, and Brendan Smith. 2002. Globalization from Below: The Power of Solidarity. Cambridge: South End Press.

Campaign for Labor Rights (CLR). Various years. Online, http://www.clrlabor.org.

Castelles, Manuel. 1989. The Informational City. Blackwell: Oxford.

Cave, Michael. 2002. "Just Change It." Australian Financial Review. June 14.

Collingsworth, Terry. 1998. "An Enforceable Social Clause.” Foreign Policy in Focus (3)28: 1-3.

Connell, Tula. 2001. "Maquila Melee: Death Threats and Plant Closings Threaten Workers Rights in Guatemala." In These Times. Dec. 7.

della Porta, Donatella, Hanspeter Kreisi, and Dieter Rucht. 1999. Social Movements in a Globalizing World. New York: St. Martin's Press.

Dicken, Peter. 1998. Global Shift: Transforming the World Economy. New York: Guilford Press.

Evans, Peter. 2000. "Fighting Marginalization with Transnational Networks: Counter-hegemonic Globalization." Contemporary Sociology 29(6): 230-41.

Falk, Peter. 1993. Global Visions: Beyond the New World Order. Boston: South End Press.

Faux, Jeff. 2002. "Corporate Control of North America." The American Prospect 3(4). Online edition, http://www.prospect.org/web.

Featherstone, Liza. 2002. Students Against Sweatshops. Verso: New York.

Fox, Jonathon. 2000. "The World Bank Inspection Pannell: Lessons for the First Five Years." Global Governance 6(3): 279-318.

Fung, Archon, Dara O'Rourke and Charles Sabel. 2001. Can We Put An End to Sweatshops? Boston: Beacon Press.

Gilley, Bruce. 2001. "Sweating It Out." Far Eastern Economic Review. Available online at http://www.feer.com/010510/p.o4innov.html.

Greenhouse, Steven. 1997. "Accord to Combat Sweatshop Labor Faces Obstacles." New York Times. April 13.

Guidry, John, Michael Kennedy, and Mayer Zald, eds. 2000. Globalization and Social Movements: Culture, Power and the Transnational Public Sphere. Ann Arbor, Michigan: University of Michigan Press.

Keck, Margaret and Kathryn Sikkink. 1998. Activists Beyond Borders: Advocacy Networks in International Politics. Ithaca, NY: Cornell University Press. 
Kepne, Alison. 2000. "For Two Students, Spring Break Trips Offer a Glimpse into Clothing Factories." The Digital Collegian. April 13.

Khagram, Riker and Kathryn Sikkink. 2002. Restructuring World Politics: Transnational Social Movements, Network and Norms. Minneapolis: University of Minnesota Press.

Kidd, Dusty. 2001. "Kukdong/Mexmode Update From Nike.” Available online at http://www.nikebiz. org. November 30.

Korten, David. 2001. When Corporations Rule the World. Bloomfield, IN: Kumarian Press.

Mann, Michael. 2000. "Has Globalization Ended the Rise of the Nation-State?" Pp. 136-147 in The Global Transformations Reader: An Introduction to the Globalization Debate, David Held and Anthony McGrew, eds. Cambridge: Polity Press.

Maquila Solidarity Network. 2001. "Nike Concedes Victory: Sportswear Giant Promises to Place Orders with Unionized Factory." December 12.

Manye, Gregory. 2002. "Transnational Structures and Protest: Linking Theories and Assessing Evidence.” Pp. 31-50 in Globalization and Resistance: Transnational Dimensions of Social Movements, Jackie Smith and Hank Johnston, eds. Lanham: Rowman and Littlefield Publishers.

McAdam, Doug. 1998. "On the International Origins of Domestic Political Opportunities.” Pp. 251-267 in Social Movements and Political Institutions in the United States, Anne Costain and Andrew McFarland, eds. Boulder, CO: Rowman \& Littlefield.

-1996. Power in Movement: Social Movements, Collective Action and Mass Politics in the Modern State. Cambridge: Cambridge University Press.

-1982. Political Process and the Development of Black Insurgency, 1930-1970. Chicago: University of Chicago Press.

MHSSN (Maquiladora Health \& Safety Support Network). 2001. 5(4). December 9.

O'Brien, Robert, Anne Goetz, Jan Scholte, and Marc Williams. Contesting Global Governance: Multilateral Economic Institutions and Global Social Movements. New York: Cambridge University Press.

Ribeiro, Gustavo Lins. 1998. "Cybercultural Politics: Political Activism at a Distance in a Transnational World.” Pp. 325-352 in Cultures of Politics, Politics of Cultures, Sonia Alvarez, Evelina Dagnino and Arturo Escobar, eds. Boulder, CO: Westview Press.

Risse, Thomas and Kathyrin Sikkink. 1999. "The Socialization of International Human Rights Norms into Domestic Practices.” Pp. 1-38 in The Power of Human Rights and Domestic Change, Thomas Risse, Stephen Ropp, and Kathryn Sikkink, eds. Cambridge: Cambridge Press.

Rodrik, David. 2000. "Has Globalization Gone Too Far? Pp. 323-327 in The Global Transformations Reader: An Introduction to the Globalization Debate, David Held and Anthony McGrew, eds. Cambridge: Polity Press.

Rothman, Daniel and Pamela Oliver. 2002. "From Local to Global: The Anti-Dam Movement in Southern Brazil, 1979-1992." Pp. 115-132 in Globalization and Resistance: Transnational Dimensions of Social Movements, Jackie Smith and Hank Johnston, eds. Lanham: Rowman and Littlefield Publishers.

Rucht, Dieter. 1999. "The Transnationalization of Social Movements: Trends, Causes and Problems." Pp. 76-105 in Social Movements in a Globalizing World, Donatella della Porta, Hanspeter Kriesi, and Dieter Rucht, eds. New York: Macmillan.

Schrader, Jordan. 2002. "Sweatshop Worker Credits University of Michigan for Better Working Conditions." Michigan Daily. Dec. 4.

Seidman, Gay. 2000. "Adjusting the Lens: What Do Globalizations, Transnationalism, and the AntiApartheid Movement Mean for Social Movement Theory?" Pp. 339-357 in Globalization and Social Movements, John Guidry, Michael Kennedy, and Mayer Zald, eds. Ann Arbor, Michigan: University of Michigan Press.

Sikkink, Kathryn and Jackie Smith. 2002. "Infrastructures for Change: Transnational Organizations, 1952-1993.” Pp. 24-43 in Restructuring World Politics: Transnational Social Movements, Networks and Norms, Sanjeev Khagram, Kathryn Sikkink, and James Riker, eds. Minneapolis: University of Minnesota Press.

Sklair, Leslie. 1998. Social Movements and Global Capitalism: The Cultures of Globalization. Durham: Duke University Press.

. 1995. Assembling for Development: The Maquila Industry in Mexico and the United States. San Diego: Center for U.S.-Mexican Studies, University of California at San Diego. 
Smith, Jackie. 2002. "Globalizing Resistance: The Battle of Seattle and the Future of Social Movements." Pp. 207-227 in Globalization and Resistance: Transnational Dimensions of Social Movements, Jackie Smith and Hank Johnston, eds. Lanham, MD: Rowman and Littlefield.

Smith, Jackie, and Hank Johnston. 2002. "Globalization and Resistance: An Introduction." Pp. 1-12 in Globalization and Resistance: Transnational Dimensions of Social Movements, Jackie Smith and Hank Johnston, eds. Lanham, MD: Rowman and Littlefield.

Smith, Jackie, Charles Chatfield, and Ron Pagnuccio, eds. 1997. Transnational Social Movements and Global Politics. Syracuse: Syracuse University Press.

Snow, David, and Robert Benford. 1988. "Ideology, Frame Resonance and Participant Mobilization." Pp. 197-217 in From Structure to Action: Comparing Social Movement Research Across Cultures, Bert Klandermanns, Hanspeter Kriesi, and Sidney Tarrow, eds. Greenwich, CT: JAI press.

Spar, Debora, and David Yoffe. 1999. "Multinational Enterprises and the Prospects for Justice." Journal of International Affairs 52(2): 557-581.

Strange, Susan. 2000. "The Declining Authority of States.” Pp. 148-155 in The Global Transformations Reader: An Introduction to the Globalization Debate, David Held and Anthony McGrew, eds. Cambridge: Polity Press.

Tarrow, Sidney. 2002. "From Lumping to Splitting: Specifying Globalization and Resistance." Pp. 229249 in Globalization and Resistance: Transnational Dimensions of Social Movements, Jackie Smith and Hank Johnston, eds. Lanham, MD: Rowman and Littlefield.

- 2001. "Transnational Politics." Annual Review of Political Science 4(1): 1-20.

. 1998. Power in Movements: Social Movements and Contentious Politics. Cambridge: Cambridge University Press.

- 1995. "The Europeanization of Conflicts: Reelections form a Social Movement Perspective." Western European Politics 18(2): 223-51.

Verite. 2001. "Comprehensive Factory Evaluation Report on Kukdong International Mexico, S.A. De C.V. Atlxico, Puebla Mexico.” Available online at http://www.verite.org

Winston, Morton. 2002. "NGO Strategies for Promoting Corporate Social Responsibility." Ethics and International Affairs 16(1): 71-88.

WRC (Worker's Rights Consortium). 2002. Available online at http://www.workersrights.org. 